\title{
Corporate Governance and the Earnings Quality of Nigerian Firms
}

\author{
Festus Oladipupo Olaoye $^{1} \&$ Ademola Adeniran Adewumi ${ }^{2}$ \\ ${ }^{1}$ Department of Accounting, Ekiti State University, Nigeria \\ ${ }^{2}$ Department of Accounting, Federal Polytechnic, Ile-Oluji, Nigeria \\ Correspondence: Ademola Adeniran Adewumi, Department of Accounting, Federal Polytechnic, Ile-Oluji, Nigeria.
}

Received: May 2, 2020

doi:10.5430/ijfr.v11n5p161
Accepted: July 7, 2020

Online Published: September 21, 2020

URL: https://doi.org/10.5430/ijfr.v11n5p161

\begin{abstract}
The focus of the study is to examine the impact of corporate governance on earnings quality in listed firms in Nigeria. The specific objective is to investigate the effect of board size, board independence and board gender diversity on earnings quality. This study was carried out with secondary data retrieved from corporate annual reports of the sampled companies and the data was analysed using panel regression on a sample of 37 quoted manufacturing companies for the period 2011-2017. On the overall, the result reveals that Board size, board independence and board gender diversity used for measuring corporate governance show significant impact on earnings quality. In addition, corporate governance variables appear to be quite sensitive to the measure of earnings quality used. Based on the findings, the study recommends the need for comprehensive evaluation of corporate governance systems of companies. The study recommends the need for more level of board independence. The diversity issue though is gaining momentum in corporate governance literature can still be regarded as not as dominant as compared to others especially as it relates to protecting shareholder rights and framing dividend policy. The significance of the variable nevertheless suggests that companies should thrive to achieve an appropriate diversity mix.
\end{abstract}

Keywords: earning quality, corporate governance, board size, board independence, board gender diversity, discretionary accruals

JEL Classification: M41, E27, G35

\section{Introduction}

Earnings typically represent the net income resulting from operations of a corporation and it is the basis for computing tax liability of the entity. Thus earnings are indicators for assessing the financial performance of a company (Francis, Ryan, Olsson, and Schipper 2003). With emphasis on the concept of earnings quality, Schipper \& Vincent (2003) notes that earnings quality can be defined as the predictive ability of reported earnings in relation to future earnings. In other words, earnings can be categorized as having higher quality if previous earnings can be used to predict future earnings. This is one of the reasons why accounting standards are constantly been updated in order to improve quality of reported earnings that is free from manipulation (Dang, Pham' Nguyen \& Nguyen' 2020). However, the concept of earnings quality is multidimensional in nature and can be understood from several perspectives. First, there is earnings management which is the act of intentionally influencing the process of financial reporting to obtain some private gain. Second is the earnings persistence which focuses largely on the continuity and durability of the current earnings. The third earnings quality dimension is the earnings predictability which looks at the predictive characteristics of earnings. All three dimensions are important and present unique perspectives on earnings quality.

The factors that determine earnings quality is a huge area of enquiry in accounting research and in this regard, Francis, et al. (2006) divided the factors that determine earnings quality into two groups: the innate and the reporting sources. The first group consists of factors relating to the business model, corporate attributes and the overall environment of the firm, whereas the second group focuses on the reporting standards and then also, management's financial reporting decisions. Soderstrom and Sun (2007) observed that the amongst the very crucial factors under the first group identified by Francis, et al. (2006) is the corporate governance structure of the firm. Therefore, the relationship between corporate governance and earnings quality measures is one that has garnered lots of research attention. Ozili, (2020) points out the corporate governance provides the defence of shareholders from opportunistic tendencies of management which is mirrored by the earnings quality. However, our assessment of extant studies in this regard have shown mixed results such as weak, insignificant or even inconsistent linkages (Hussaini, Bala, Gugong, and Benjamin 
2013; Dwi Lusi 2013; Nelson and George 2013). A keen observation of a number of studies on earnings quality conducted in Nigeria such as Ibadin and Dabor (2015), Samaila (2014), Hassan (2013), Hassan and Bello (2013) Imeokparia, (2013), Adeyemi and Uadiale (2010), Asogwa, Ofoegbu, Nnam \& Chukwunwike (2019), Ozili, (2020) and Dabor and Adeyemi (2009) in Nigeria, reveals the dominance of accrual measures for earnings quality using either the Jones or Modified Jones Model or the Dicheow and Dichev (2002) model. Accrual earnings management represents just one measure and perspective of earnings quality and there are other important dimensions such as earnings persistence and earnings predictability. This study addressed this gap by employing earnings persistence and earnings predictability dimensions of earnings quality. The main objective of this study was to investigate the effects Corporate Governance (board size, board independence and board gender diversity) on Earnings Quality in Nigerian Quoted Companies.

\section{Literature Review}

\subsection{Earnings Quality}

Richardson, Sloan, Soliman and Tuna (2001) viewed earnings quality on the basis of the level of stability of current earnings in future periods. Hence the focal point of their conceptualization of earnings quality is that earnings that show high quality are more stable and less volatile. This view of earnings quality is also shared by Penman (2003) who pointed out that earnings has good quality if earnings in the current period can be used to forecast the possible earnings in the future period. However, it is noted in the literature that there is no one way to look at earnings quality as several characteristics of earnings have varying levels of importance to stakeholder. Therefore, researchers used different criteria for measuring this variable. Indexes that have been used more in researches for measuring earnings quality include: Accrual items quality, earnings stability and earnings forecast ability (Soghra \& Vakilifard, 2015).

Srinidhi, Gul, and Tsui (2011) described earnings quality as the ability of current reported earnings to reflect the future cash flow and earnings. In this context, earnings quality refers to how best current reported earnings can predict future performance of an entity. Similarly, Bellovary, Giacomino and Akers (2005) and Li (2011) defined earnings quality as the ability of earnings to reflect a company's permanent earnings. Dechow, Ge, and Schrand (2010) defined the quality of earnings as the relevance of the fundamental earnings reported to the decision context of users. Our working definition is earnings quality refers to the ability of reported earnings (income) to predict a firm's future earnings.

\subsection{Measures of Earnings Quality}

\section{(i). Accrual Quality}

According to Richardson et al. (2001) and Desai, Krishnamurthy \& Venkatarama (2006) accrual quality is the difference between cash resulting from business transactions and the earnings. In detecting the level of accrual quality, Dechow and Dichev (2002) had gone ahead to develop a model that has been widely used in accounting research to show the quality of accruals. The hallmark of the model is that it takes a perspective on accounting information quality based on the variations in accruals indicated by the standard deviation of accruals. They affirmed that accruals had a direct relationship with cash, and that the errors in the connection were negatively related with the quality of accounting information. This perspective has been used by studies to examine the quality of earnings (Dechow, Ge \& Schrand, 2010Ball \& Shivakumar, 2006; Larcker, Richardson \& Tuna, 2007).

\section{(ii). Persistence}

Another indicator of the earnings quality is the persistence of the reported earnings which is often measured as the extent to which earnings are sustained (Penman \& Zhang 2002; Francis, et al. 2004). It is believed that earnings that are more persistent tend to show a high level of sustainability and thus have high quality. In the same vein, earnings which are less persistent are more transitory and seen to exhibit lower quality (Penman \& Zhang 2002; Francis et al. 2004). Therefore, earnings persistence refers the ability of reported earnings to display stability and sustainability over time. According to Francis et al., (2004) earnings persistence can be defined as the systematic behaviuor of earnings, and persistent earnings are viewed as desirable because they reoccur (Francis et al., 2004).

\section{(iii). Predictability}

According to Penman \& Zhang (2002), earnings predictability can be defined as the ability of earning to predict a future component of operating income. Therefore, the more precise the ability of report earnings to forecast future earnings, the higher the level of earnings predictability and hence high earnings quality and vice-versa. This attribute is measured based on the variance of the earnings shocks, where higher variance implies lower predictability. Earnings predictability has been measured with this method which was proposed initially by Lipe (1990) and by other researchers such as Francis et al. (2004), Cascino et al. (2010) and Kousenidis et al. (2013). 


\subsection{Corporate Governance}

The concept of corporate governance constantly remains a germane issue as far as businesses are concerned. It is also an area that as enjoyed robust attention and thus several definitions of the concept exist in extant literature. For example, Liu, Harris, and Omar (2013) view corporate governance as an internal mechanism to improve shareholders interest and managers accountability. This is also the position of Shukeri and Aminul (2012) though the place importance on management control as a vital function of corporate governance and the ultimate aim being to ensure longevity of the enterprise. Alawattage and Wickramasinghe (2004) take a wider view of the concept noting that corporate governance covers institutional rules, norms, and laws. World Bank (2002) and the Organization of Economic Cooperation and development (OECD, 1999) similar to the view of Shukeri and Aminul (2012), Hopt (2011), Fatimoh (2012) and Sanda, Mikailu \& Garba, 2005) listed several corporate governance mechanism both internal and external. However, this study focuses on internal corporate governance mechanisms with particular attention to board characteristics.

\subsection{Empirical Review}

\subsubsection{Board Independence and Earnings Quality}

Basically, the level of independence of the board can be looked at from the perspective of the number of non-executive directors or outside directors that are on the board. In a case where the board has a reasonable proportion non-executive directors, that board can be seen as more independent when compared to the case where the board is dominated by inside directors. Several studies have attempted to examine the relationship between board independence and earnings quality. For example, Euphrasia and Dini (2013) focused on the banking industry in Ghana and found results confirming that board independence structure had a negative significant impact on the level of earnings management. Yeh and Chou (2014) doing a cross-county study covering Malaysia, Hong Kong, and Singapore also showed from their study findings that the presence of independent directors on the board and particularly those that have background in accounting, finance or law is generally effective for improving the quality of earnings. In line with Yeh and Chou (2014), Gonzale and Garcia-Meca (2014) examined the same issue using a sample of listed Latin American non-financial companies from the period 2006-2009 and the linear regression results showed that independent directors improved earnings quality. In addition, Shiri, Vaghfi, Soltani and Esmaeli (2012) provided empirical evidence using firms listed in the Stock Exchange in Iran also revealed findings that support a significant and positive relationship between the ratio of independent members to persistent and earning predictability. Consequently, the hypothesis is specified thus;

\section{$H_{01}$ : Board independence has no significant impact on Earnings quality of quoted companies in Nigeria.}

\subsubsection{Board Size and Earnings Quality}

Board size refers to the number of individuals on the board. There are several arguments in relation to whether a large board or a small board size which is more effective and the discourse has largely not moved towards a consensus. On the empirical side, studies have also examined the relationship between board size and several organisational outcomes but in relation to earnings quality, Juan (2012) this relationship using a sample of 90 listed Mexican firms covering the period 2005-2009. The finding revealed that board size has a positive effect on earnings quality. Similar findings is reported by Cristina (2010) using a sample of Portuguese companies. Also going in the same direction, is the findings of Abed, Al-Attar and Suwaidan (2012) using sample of Jordanian non-financial firms during the period 2006-2009. Their results showed that board size has a positive and significant impact on earnings quality. Dang, Pham' Nguyen and Nguyen (2020) investigated the relationship between corporate governance and earnings quality using a sample of firms in Vietnam covering the period from 2008-2018. The study made use of the generalized least squares regression technique. The results show that the board size has a significant and positive effect on earnings quality. On the contrary, Fodio, Ibikunle and Oba (2013) examined the relationship between board size and earnings quality using insurance companies in Nigeria. The results from the estimation showed that board size is negatively related to earnings quality and is also significant at 5\%. Similarly, Ibadin and Dabor (2015) using a larger sample size of 100 companies in Nigeria also found that the relationship between board size and earnings quality is negative and significant. Consequently, the hypothesis is specified thus;

$H_{02}$ : Board Size has no significant impact on Earnings quality of quoted companies in Nigeria.

\subsubsection{Board Diversity and Earnings Quality}

Board gender diversity for the purpose of this study deals with the female to male ratio of the board (Bear, Rahman, \& Post, 2010). There is the argument that the female presence on the board introduces some dynamics in board interactions and this can ultimately affect the outcomes at the board level. This point is also dominant in the position of 
Johnson et al. (2013) which also argues that boards that are diverse in terms of gender composition experience some board dynamics resulting from cognitive differences and this also has a way of influencing the firm-level outcomes. Looking at the empirical investigation on board gender diversity and earnings quality, Makhlouf, Al-Sufy and Almubaideen (2018) employing a sample of 68 industrial firms quoted on Amman Stock Exchange (ASE) from 2013-2016 found the existence of a positive and significant relationship between gender diversity and accounting earnings quality. In a similar vein, Boussaid and Sougné (2015) providing empirical evidence for French listed firms for the period 2009-2012 also revealed the presence of a positive and significant relationship between board gender diversity and earnings quality.

Using a sample of 13,206 firm years listed in the USA for a period from 1996-2008, Ho et al. (2015) focused on the CEO gender found that there is a positive and strong relationship between CEO gender and accounting quality. García et al. (2017) adopting a cross-country approach covering the banks in the euro-zone with a total sample of 159 banks and covering the period 2004-2010. The findings of the study indicates that the presence of females on the board have a positive impact on earnings quality. On the contrary, Wang (2015) examined the relationship between board gender diversity and accounting conservatism used as an indicator of earnings quality. The study made use of 25 firms listed in the Finnish exchange covering the period 2009-2014 and the results showed that board gender diversity has no significant effect on conditional accounting conservatism. Consequently, the hypothesis is specified thus;

\section{$H_{03}:$ Board Gender diversity has no significant impact on Earnings quality of quoted companies in Nigeria.}

\section{Theoretical Framework}

\section{The Resource-Based View (RBV)}

The issue of what drives firms actions and in this context pursuing earnings quality have been central in strategy research for decades and encompasses most other questions that have been raised in the field, as for instance, why firms differ, how they behave, how they choose strategies and how they are managed (Porter,1991). In the 1990s, with the rise of the resource-based approach, strategy researchers' focus regarding the sources of sustainable competitive advantage shifted from industry to firm specific effects. Initiated in the mid-1980s by Wernerfelt (1984), Rumelt (1984) and Barney (1986), the resource-based view (RBV) has since become one of the dominant contemporary approaches to the analysis of why firms do what they do. The resource based view is chosen because the theory sees corporate governance as a resource for the firm that can account for organisational outcomes such as the earning quality. In the light of the theory, corporate governance is an internal resource that has the potential for providing competitive advantage for the firm. The theory thus properly, places corporate governance as a vital tool unique to the firm which determines how they behave, how they choose strategies and how they are managed. In the light of earnings quality, the theory sees corporate governance as a resource for the firm that can account for organisational outcomes such as the earning quality

\section{Methodology}

This study employed the ex-post causal research design. The study utilizes a sample of 37 manufacturing companies quoted on the Nigerian Stock Exchange. The simple random sampling was used for the selection. The data was retrieved from corporate annual reports of the sampled companies for 2011-2017 financial years. The effect of corporate attributes on earnings quality was analyzed using panel regression. The pooled OLS, random effects (RE) and fixed effects (FE) were all estimated. The hausman test statistic is employed as the estimation selection criteria between the FE and RE estimations and the Wald test is also examined to check the poolability of the data. Preliminary analysis such as the descriptive statistics, correlation analysis and test for multicollinearity were also conducted and post-estimation diagnostics such as the test for serial correlation, heteroskedasticity and Ramsey rest test were also examined.

\section{Model Specification}

This model examines the effect of governance attributes on earnings quality. The model is presented below;

$$
\mathrm{EQ}=f(\mathrm{CG})
$$

Decomposing corporate governance into some selected components, we have;

$$
\mathrm{EQ}=f(B S, B I N D, B G D)
$$

Specifying the econometric form, we have;

$$
\left(E Q_{i i}\right)=\beta_{0}+\beta_{1} B S_{i t}+\beta_{2} B I N D_{i t}+\beta_{2} B D G_{i t}+v_{i t}+\varepsilon_{i t}
$$


Disaggregating earnings quality into the three measures; discretional accruals (DISACC), Earnings persistence (PERS) and earnings predictability (PREDIC), we have;

$$
\begin{aligned}
\left(\text { DISACC }_{i i}\right) & =\beta_{0}+\beta_{1} B S_{i t}+\beta_{2} \text { BIND }_{i t}+\beta_{2} B D G_{i t}+v_{i t}+\varepsilon_{i t} \\
\left(\text { PERS }_{i i}\right) & =\beta_{0}+\beta_{1} B S_{i t}+\beta_{2} B I N D_{i t}+\beta_{2} B D G_{i t}+v_{i t}+\varepsilon_{i t} \\
\left(\text { PREDIC }_{i i}\right) & =\beta_{0}+\beta_{1} B S_{i t}+\beta_{2} B I N D_{i t}+\beta_{2} B D G_{i t}+v_{i t}+\varepsilon_{i t} .
\end{aligned}
$$

Where $\mathrm{EQ}=$ Earnings quality, $\mathrm{BIND}=$ Board independence, $\mathrm{BGD}=$ Board gender diversity, $\mathrm{BS}=$ Board Size meeting $\mu_{i t}=$ random error, $f_{i t}=$ cross-sectional fixed error.

\begin{tabular}{|c|c|c|c|}
\hline Variable & Description & Measurement & Aprori sign \\
\hline \multicolumn{4}{|c|}{ Dependent Variable } \\
\hline \multirow{3}{*}{ EQ } & \multirow{3}{*}{ Earnings Quality } & $\begin{array}{l}\text { Earnings persistence measured as the slope } \\
\text { of an } \operatorname{ar}(1) \text { earnings model }\end{array}$ & \\
\hline & & $\begin{array}{l}\text { Earnings predictability measured as the } \\
\text { residual of an } \operatorname{ar}(1) \text { earnings model }\end{array}$ & \\
\hline & & $\begin{array}{l}\text { Discretionary accruals measured using } \\
\text { Modified Jones (2001) model }\end{array}$ & \\
\hline \multicolumn{4}{|c|}{ Independent variables } \\
\hline $\mathrm{BS}$ & Board size & Number of individuals on the board & + \\
\hline BIND & Board independence & $\begin{array}{l}\text { Number non-executive directors on the } \\
\text { board. }\end{array}$ & + \\
\hline BDG & Board gender diversity & Male-female ratio on the board & - \\
\hline
\end{tabular}

Aprori signs; $\beta_{1}>0, \beta_{2}>0, \beta_{3}>0, \beta_{4}<0$ and $\beta_{5}>0$

Table 1. Variable description and measurement

Source: Compilation by the authors, 2019

\section{Presentation of Result}

Table 2. Descriptive statistics

\begin{tabular}{lcccccc}
\hline & Mean & Maximum & Minimum & Std. Dev. & Jarque-Bera & Prob \\
\hline BSIZE & 10.02841 & 20 & 4 & 3.256252 & 26.24532 & 0.000 \\
\hline BDIND & 0.63 & 0.82 & 0.17 & 2.766729 & 273.732 & 0.000 \\
\hline BDIV & 2.165739 & 5 & 0 & 1.163229 & 580.8837 & 0.00 \\
\hline DISCC & 0.063409 & 4.203688 & -2.15753 & 0.323982 & 155799.2 & 0.00 \\
\hline PERS & 0.219 & 0.73474 & $-2.2 \mathrm{E}+07$ & 1706743 & 445634.6 & 0.00 \\
\hline PREDIC & -10.2077 & 914.6776 & -13486 & 724.4367 & 1706296 & 0.00 \\
\hline
\end{tabular}

Source: Researcher's compilation (2019)

Where: BDIV= Board gender diversity, $\mathrm{BIND}=$ Board independence, $\mathrm{BS}=$ Board Size DISCC $=$ Discretionary accruals, $\mathrm{PERS}=$ Earnings Persistence and $\mathrm{PREDIC}=$ Earnings predictability

The descriptive statistics of the data is presented in Table 2 above. As observed, the average Board size is about ten (10) with a maximum value of 20 and minimum value of 4 respectively. The standard deviation showing the dispersion of the data about the mean is quite low at 2.766. The Jacque-bera value of 26.245 and p-value of 0.00 confirms the normality of the data. BDIND has an average value of 0.63 which indicates that about $63 \%$ of board members are independent members with maximum and minimum values of 0.82 and 0.17 respectively. The standard deviation of 2.766 is quite low which suggest considerable clustering around the distribution mean. The Jacque-bera 
value of 273.732 and p-value of 0.00 confirms the normality of the data. The Board gender diversity is 2.165 which suggest that on the average two board members are females. The maximum and minimum values are 5 and 0 respectively. The Jacque-bera value of 580.8837 and p-value of 0.00 confirms the normality of the data. The average DISCC is 0.063 with maximum and minimum values of 4.2036 and -2.1575 respectively. The Jacque-bera value of 40.4915 and p-value of 0.00 confirms the normality of the data. The average earnings persistence estimate is about 0.219 with maximum and minimum values of 0.734 and 0.12 respectively with a standard deviation of 170.743 . The Jacque-bera value of 44.5 and p-value of 0.00 confirms the normality of the data. The mean value for earnings predictability stood at -10.2077 with maximum and minimum values of 91.6776 and -0.3486 respectively with a standard deviation of 724.436. The Jacque-bera value of 170.629 and p-value of 0.00 confirms the normality of the data.

Table 3. Pearson correlation matrix

\begin{tabular}{lcccccc}
\hline & BSIZE & BDIND & BDDIV & DISCC & PERS & PREDIC \\
\hline BSIZE & 1 & & & & & \\
\hline BDIND & 0.5835 & 1 & & & & \\
\hline BDDIV & 0.53129 & 0.8692 & 1 & & & \\
\hline DISCC & 0.03468 & 0.0099 & 0.0216 & 1 & & \\
\hline PERS & -0.0095 & 0.0024 & 0.001 & 0.00177 & 1 & 1 \\
\hline PREDIC & -0.0638 & -0.071 & -0.0418 & 0.00098 & 0.7203 & \\
\hline
\end{tabular}

Source: Researcher's compilation (2019)

From Table 3, the correlation coefficients of the variables are examined. However of particular interest to the study is the correlation between earnings quality measures (DISCC, PERS and PREDIC) and the independent variables. As observed, correlation exists between DISACC and the following variables; BSIZE ( $r=0.034)$, BDIND ( $r=0.009$ ), $\operatorname{BDDIV}(\mathrm{r}=0.0216)$. The correlation estimates exists between PERS and the following variables; BSIZE $(\mathrm{r}=-0.009)$, BDIND ( $\mathrm{r}=0.0024)$, BDDIV $(\mathrm{r}=0.001)$. The correlation estimates exists between PREDIC and the following variables; BSIZE ( $r=-0.064)$, BDIND $(r=-0.071)$, BDIV $(r=-0.042)$.The positive coefficient suggests that an increase in these variables could be associated with increases in earnings quality and vice-versa.

Table 4. Variance inflation factor test

\begin{tabular}{cc}
\hline Variable & VIF \\
\hline BSIZE & 1.9151 \\
\hline BDIND & 4.910936 \\
\hline BDIV & 4.615146 \\
\hline
\end{tabular}

Source: Researcher's compilation (2019)

Multicollinearity among the independent variables implies that they are perfectly correlated. If there exists perfect correlation between the independent variables, the parameter coefficients will be indeterminate. In this study, the variance inflation factor (VIF) test is constructed to test for multicollinearity. Essentially, VIFs above 10 are seen as a cause of concern as observed, none of the variables have VIF's values more than 10 and hence none gave serious indication of multicollinearity.

Table 5. Corporate governance and earnings quality

\begin{tabular}{cccccccccc}
\hline & \multicolumn{3}{c}{ Discretionary Accruals } & \multicolumn{2}{c}{ Earnings Persistence measure } & \multicolumn{3}{c}{ Earnings Predictability Measure } \\
\hline Estimators & $P O L S$ & $F E$ & $R E$ & $P O L S$ & $F E$ & $R E$ & $P O L S$ & $F E$ & $R E$ \\
\hline \multirow{2}{*}{$\mathrm{C}$} & -0.13012 & -0.01389 & -0.13130 & 0.40508 & 0.33478 & 0.2768 & 313.8936 & $-40.68^{* *}$ & 315.4569 \\
\cline { 2 - 26 } & $(0.1287)$ & $(0.0223)$ & $(0.1311)$ & $(0.0859)$ & $(0.0383)$ & $(0.1014)$ & $(283.00)$ & $(22.6119)$ & $(283.930)$ \\
\hline
\end{tabular}




\begin{tabular}{|c|c|c|c|c|c|c|c|c|c|}
\hline & $\{0.3126\}$ & $\{0.5339\}$ & $\{0.3179\}$ & $\{0.000\}$ & $\{0.000\}$ & $\{0.0055\}$ & $\{0.2679\}$ & $\{0.0738\}$ & $\{0.2671\}$ \\
\hline \multirow{3}{*}{$B D S$} & 0.00472 & $0.0033^{*}$ & $0.0048 * *$ & -0.0062 & -0.00154 & -0.0032 & -7.4493 & 0.58523 & $-7.488 * *$ \\
\hline & $(0.0028)$ & $(0.0007)$ & $(0.0029)$ & $(0.0039)$ & $(0.0017)$ & $(0.0055)$ & $(7.46857)$ & $(0.43391)$ & $(7.4832)$ \\
\hline & $\{0.1010\}$ & $\{0.000\}$ & $\{0.0989\}$ & $\{0.1165\}$ & $\{0.3682\}$ & $\{0.5646\}$ & $\{0.3191\}$ & $\{0.1793\}$ & $\{0.3176\}$ \\
\hline \multirow{3}{*}{$B I N D$} & -0.0076 & $-0.0070 *$ & -0.0075 & $0.02053 *$ & 0.0096 & $0.0173^{*}$ & -8.69987 & $40.2141 *$ & -8.69725 \\
\hline & $(0.0052)$ & $(0.0031)$ & $(0.0053)$ & $(0.0102)$ & $(0.0080)$ & $(0.0098)$ & (16.51336) & (11.0618) & $(16.5211)$ \\
\hline & $\{0.1465\}$ & $\{0.0266\}$ & $\{0.1568\}$ & $\{0.0456\}$ & $\{0.3682\}$ & $\{0.0797\}$ & $\{0.5986\}$ & $\{0.0004\}$ & $\{0.5988\}$ \\
\hline \multirow{3}{*}{$B D I V$} & 0.00366 & $-0.00494 * *$ & 0.00324 & $0.0205^{*}$ & $-0.01284 *$ & -0.02745 & 20.03661 & $-11.638 *$ & 20.1108 \\
\hline & $(0.01414)$ & $(0.0027)$ & $(0.0142)$ & $(0.0102)$ & $(0.00614)$ & $(0.0167)$ & $(25.1997)$ & $(4.5218)$ & $(25.2284)$ \\
\hline & $\{0.7960\}$ & $\{0.0734\}$ & $\{0.8201\}$ & $\{0.0174\}$ & $\{0.0370\}$ & $\{0.1010\}$ & $\{0.4270\}$ & $\{0.0109\}$ & $\{0.4258\}$ \\
\hline$R^{2}$ & 0.0131 & 0.361 & 0.0128 & 0.4181 & 0.731 & 0.0163 & 0.0197 & 0.697 & 0.0197 \\
\hline $\operatorname{Adj} R^{2}$ & 0.0014 & 0.223 & 0.0012 & 0.4086 & 0.716 & 0.0047 & 0.0048 & 0.510 & 0.0048 \\
\hline F-Stat & 1.124 & 2.6259 & 1.102 & 44.022 & 62.738 & 1.407 & 1.3248 & 37.356 & 1.3250 \\
\hline$P(f$-stat $)$ & 0.346 & 0.0000 & 1.102 & 0.00 & 0.00 & 0.1994 & 0.236 & 0.0000 & 0.2364 \\
\hline D. W & 2.08 & 2.23 & 2.08 & 2.30 & 2.30 & 1.4 & 2.62 & 1.9 & 2.629 \\
\hline \multicolumn{10}{|c|}{ Diagnostic Test } \\
\hline Wald Test & & 0.000 & & & 0.000 & & & 0.0441 & \\
\hline Hausman & & 0.011 & & & 0.021 & & & 0.000 & \\
\hline $\begin{array}{c}\text { B-P-G } \\
\text { Test }\end{array}$ & & 0.483 & & & 0.117 & & & 0.893 & \\
\hline B-G Test & & 0.779 & & & 0.209 & & & 0.554 & \\
\hline $\begin{array}{c}R \text {-Ramsey } \\
\text { Test }\end{array}$ & & 0.410 & & & 0.482 & & & 0.198 & \\
\hline
\end{tabular}

Source: Researcher's compilation (2019) and are p-values, $(*) 1 \%$ sig, $(* *)$ at $5 \%$ sig \& (***) at $10 \%$ sig.

Table 5 shows the regression results of the Pooled OLS, Random effects (RE) and fixed effects (FE) models. To determine which model is better, this research conducted a Wald- F-test for the FE vs the pooled OLS model and the Hausman test for choosing the FE model versus the RE model. The Wald $\mathrm{f}$-test rejects the hypothesis that all $\beta=0$ and hence pooling the data will provide bias estimates. Meanwhile, the Hausman test statistic $(p=0.011)$ indicates that the RE method may give bias and inconsistent estimators when compared to FE model. Essentially, we focus on the fixed effects results. As shown in the results, the $\mathrm{R}^{2}$ for the FE model is 0.361 which implies that the model explains about $36 \%$ of the systematic variations in the dependent variable. The F-stat is 2.627 (p-value $=0.00$ ) is significant at $5 \%$ and suggest that the hypothesis of a significant linear relationship between the dependent and independent variables cannot be rejected. It is also indicative of the joint statistical significance of the model.

The analysis of coefficients reveals BDS is positive (0.033) and significant $(\mathrm{p}=0.000)$ at $5 \%$ which implies that the size of the board is a significant factor influencing discretionary accruals. BIND has a negative beta (-0.007) and significant $(\mathrm{p}=0.026)$ at $5 \%$ which implies that the independence of the board is a significant factor influencing discretionary accruals. The negative coefficient indicates that more independent boards will signal lower discretionary accruals which improve the earnings quality. BDIV has a negative beta $(-0.00494)$ and significant $(\mathrm{p}=0.0734)$ at $10 \%$. This outcome indicates that a more diverse board can decline discretionary accrual management and hence improve earnings quality. The model diagnostic shows that the estimation is free from serial correlation (B-P-G=0.483) and that the assumption of homoscedastic errors is supported ( $\mathrm{B}-\mathrm{G}=0.779)$ and the model is corrected specified (Ramsey $=0.198$ )

Table 5 shows the regression results of the Pooled OLS, Random effects (RE) and fixed effects (FE) models. Based on the Wald- F-test for the FE vs the pooled OLS model and the Hausman test for choosing the FE model versus the RE model., the FE estimation is used. As shown in the results, the $\mathrm{R}^{2}$ for the FE model is 0.731 which implies that the model explains about $73 \%$ of the systematic variations in the dependent variable. The F-stat is 62.738 (p-value = 0.00 ) is significant at $5 \%$ and suggest that the hypothesis of a significant linear relationship between the dependent and independent variables cannot be rejected. It is also indicative of the joint statistical significance of the model. 
The analysis of coefficients reveals BDS is negative (-0.0015) though not significant ( $\mathrm{p}=0.3682)$ at $5 \%$. BIND has a positive beta $(0.0096)$ though not significant $(\mathrm{p}=0.368)$ at $5 \%$. BDIV has a negative beta $(-0.0128)$ and significant $(\mathrm{p}=0.0370)$ at $5 \%$. The model diagnostic shows that the estimation is free from serial correlation (B-P-G=0.117) and that the assumption of homoscedastic errors is supported $(\mathrm{B}-\mathrm{G}=0.209)$ and the model is corrected specified (Ramsey $=0.482$ )

Table 5 shows the regression results of the Pooled OLS, Random effects (RE) and fixed effects (FE) models. As shown in the results, the $\mathrm{R}^{2}$ for the FE model is 0.697 which implies that the model explains about $68 \%$ of the systematic variations in the dependent variable. The F-stat is 37.35 (p-value $=0.00$ ) is significant at $5 \%$ and suggest that the hypothesis of a significant linear relationship between the dependent and independent variables cannot be rejected. It is also indicative of the joint statistical significance of the model. The analysis of coefficients reveals BDS is positive $(0.58523)$ though not significant $(\mathrm{p}=0.1793)$ at $5 \%$. BIND has a positive beta (40.214) and significant $(\mathrm{p}=0.000)$ at $5 \%$. BDIV has a negative beta $(-11.638)$ and significant $(\mathrm{p}=0.0109)$ at $5 \%$. The model diagnostic shows that the estimation is free from serial correlation ( $\mathrm{B}-\mathrm{P}-\mathrm{G}=0.893$ ) and that the assumption of homoscedastic errors is supported $(\mathrm{B}-\mathrm{G}=0.554)$ and the model is corrected specified (Ramsey $=0.198$ )

\subsection{Discussion of Result}

The study examines the effect of corporate governance on earnings quality using a broad range of corporate governance measures and earnings quality measure. The multifaceted nature of both concepts necessitated the need to examine them using several measures as this will provide a robust assessment of their performance. Using discretionary accrual measure, the analysis of coefficients reveals BDS is positive $(0.033)$ and significant $(\mathrm{p}=0.000)$ at $5 \%$ using accruals, BIND has a negative beta $(-0.007)$ and significant $(\mathrm{p}=0.026)$ at $5 \%$ and BDIV has a negative beta $(-0.00494)$ and significant $(\mathrm{p}=0.0734)$ at $10 \%$ Using earnings persistence measure, BDS is negative $(-0.0015)$ though not significant $(\mathrm{p}=0.3682)$ at $5 \%$. BIND has a positive beta $(0.0096)$ though not significant $(\mathrm{p}=0.368)$ at $5 \%$. BDIV has a negative beta $(-0.0128)$ and significant $(\mathrm{p}=0.0370)$ at $5 \%$. Using earnings predictability measure, BDS is positive $(0.58523)$ though not significant $(\mathrm{p}=0.1793)$ at $5 \%$. BIND has a positive beta $(40.214)$ and significant $(\mathrm{p}=0.000)$ at $5 \%$. BDIV has a negative beta $(-11.638)$ and significant $(\mathrm{p}=0.0109)$ at $5 \%$.

On the overall, the result reveals the null hypothesis $\mathrm{H}_{01}, \mathrm{H}_{02}$ and $\mathrm{H}_{03}$ is rejected as Board size, board independence and board gender diversity show significant impact on earnings quality. Though the performance of the corporate governance variables appears to be quite sensitive to the measure of earnings quality used. With discretionary accruals, all variables showed up significantly but using earnings persistence, only board gender diversity showed up significantly while Board independence and board gender showed up significantly using earnings predictability measure. The findings are in tandem with Euphrasia and Dini (2013), Yeh and Chou (2014), Gonzale and Garcia-Meca (2014) Shiri, Vaghfi, Soltani and Esmaeli (2012), Makhlouf, Al-Sufy and Almubaideen Boussaid and Sougné (2015) and García et al. (2017).

\section{Conclusion and Recommendations}

Earnings quality is one of the most important characteristics of financial reporting systems. High quality is said to improve capital market efficiency, therefore, investors and other users are interested in high-quality financial accounting information. Consequently this study attempts to examine the role of corporate governance determinants. Using a robust analysis, the findings of the study reveals that on the overall, the null hypothesis $\mathrm{H}_{01}, \mathrm{H}_{02}$ and $\mathrm{H}_{03}$ is rejected as Board size, board independence and board gender diversity show significant impact on earnings quality. Though the performance of the corporate governance variables appears to be quite sensitive to the measure of earnings quality used. With discretionary accruals, all variables showed up significantly but using earnings persistence, only board gender diversity showed up significantly while Board independence and board gender showed up significantly using earnings predictability measure.

Based on the findings, the study recommends the need for comprehensive evaluation of corporate governance systems of companies. Though there is yet no consensus on what number constitute an optimal board size, the study recommends that companies with more diverse ownership interest and shareholders needs to structure its board such that all key interest are represented. The study recommends the need for more level of board independence. Independent board members are a key component of effective corporate governance because of the expertise and objectivity that they bring to companies. The diversity issue though is gaining momentum in corporate governance literature can still be regarded as not as dominant as compared to others especially as it relates to protecting shareholder rights and framing dividend policy. The significance of the variable nevertheless suggests that companies should thrive to achieve an appropriate diversity mix. 


\section{References}

Adeyemi, S. B., \& Uadiale, O. M. (2010). The impact of firm characteristics and corporate governancevariables on audit fees in Nigeria. Nigerian Journal of Management Studies, 10(2), 1-22.

Anameje, A. C. (2007). Banking and finance professionalism in the 21st century and beyond. The Nigerian Banker, October- December Edition, 14-17.

Anandarajah, K. (2004). Corporate Governance in Asia in a Post-Enron World. In The Practitioner's Guide to Corporate Governance in Asia. Hong Kong, ISI Publications Limited.

Asogwa, Ofoegbu, G., Nnam, J., \& Chukwunwike, O. (2019). Effect of corporate governance board leadership models and attributes on earnings quality of quoted Nigerian companies. Cogent Business \& Management, 6(1) 12-34.

Ball, R., \& Shivakumar, L. (2006). The role of accruals in asymmetrically timely gain and loss recognition. Journal of Accounting Research, 44(1), 207-242.

Becker, C. L., Defond, M. L., \& California, S. (1998). The effect of audit quality on earnings management. Contemporary Accounting Research, 15(1), 1-24.

Bedard, J., Chtourou, S. M., \& Courteau, L. (2004). The effect of audit committee expertise, independence, and activity on aggressive earnings management. Auditing: A Journal of Practice and Theory, 23(1), 13-35.

Bellovary, J., Giacomino, D., \& Akers, M. (2005). Earnings quality; It's time to measure reports, CPA Journal, 75(11), 32-37.

Boussaid, N., \& Sougné, D. (2015). Corporate board attributesand conditional accounting conservatism:evidence from French firms. The Journal of Applied Business Research, 31(3), 11-31.

Carter, D. A., Simkins, B. J., \& Simpson, W. G. (2003). Corporate governance, board diversity, and firmvalue. Financial Review, 38(1), 33-53.

Cascino, S., Pugliese, A., Mussolino, D., \& Sansone, C. (2010). The influence of family ownership on the quality of accounting information. Family Business Review, 23(3), 246-265.

Cristina, G. G. (2010). Financial reporting quality and corporate governance: the Portuguese companies evidence. Unpublished Thesis submitted at the Polytechnical Institute of Coimbra.

Dabor, E. L., \& Adeyemi, S. B. (2009). Corporate governance and credibility of Financial Statements in Nigeria. Journal of Business Systems, Governance and Ethics, 4(1), 13-24.

Dang, H, Pham, C., Nguyen, T., \& Nguyen, T. (2020). Effects of Corporate Governance and Earning Quality on Listed Vietnamese Firm Value. The Journal of Asian Finance, Economics and Business, 7(4), 71-80.

Dechow, P. M., \& Dichev, D. (2002). The quality of accounting and earnings: the role of accrual estimation errors. The Accounting Review, 77(1), 193-225.

Dechow, P., Ge, W., \& Schrand, C. (2010). Understanding earnings quality: A review of proxies, their determinants and their consequence. Journal of Accounting and Economic, 50(2-3), 344-401.

Desai, H., Krishnamurthy, S., \& Venkataraman, F. (2006). Do short sellers target firm with poor quality: Evidence from earnings restatement. Review of Accounting Studies, 11(1), 71-90.

Dwi Lusi, T. S. (2013). Corporate governance, firm size, and earning management: evidence in Indonesia Stock Exchange. IOSR Journal of Business and Management, 10(4), 77-82.

Euphrasia, S. S., \& Dini, T. W. (2013). The influence of corporate governance mechanism to earnings management in Indonesia and China industrial banking. International Conference on Eurasia Economies, Session 5A: Finance 1.

Fodio, M. I., Ibikunle, J., \& Oba, V. C. (2013). Corporate governance mechanisms and reported earnings quality in listed Nigerian insurance firms. International Journal of Finance and Accounting, 2(5), 279-286.

Francis, J, Lafond, R., Olsson, M, P., \& Schipper, K. (2004). Cost of capital and Earnings Attribute. The Accounting Review, 79(4), 969-1010.

Francis, J., LaFond, R., Olsson, P. M., \& Schipper, K. (2003). The Market Pricing of Earnings Quality (October 2002). https://doi.org/10.2139/ssrn.414140 
García-Sánchez, I. M., Martínez-Ferrero, J., \& García-Meca, E. (2017). Gender diversity, financial expertise and its effects on accounting quality. Management Decision, 55(2), 347-382. https://doi.org/10.1108/MD-02-2016-0090

Gonzale, J. S., \& Garcia-Meca, E. (2014). Does corporate governance influence earnings management in Latin American markets?. Journal of Business and Ethics, 121(1), 419-440.

Hassan, S. U. (2013). Financial reporting quality, does monitoring characteristics matter? An empirical analysis of Nigerian Manufacturing Sector. The Business and Management Review, 3(2), 147-161.

Hassan, S. U., \& Bello, M. A. (2014). Firm attributes and earnings quality of listed oil and gas companies in Nigeria. Review of Contemporary Business Research, 3(1), 99-114.

Hassan, U. S. (2011). Corporate governance and financial reporting quality: A study of Nigerian money deposit bank. International Joutrnal of Research in Computer Application and Management 1(6), 2231-1009.

Hidetaka, M. (2010). Additional evidence on earnings management and corporate governance. Financial Research and Training Center, Discussion Paper Series.

Ho, M. F., \& Wen, S. Y. (2015). The influence of corporate governance in Chinese companies on discretionary accruals and real earnings management. Asian Economic and Financial Review, 5(3), 391-406.

Hussaini, B., \& Gugoing, B. K. (2013). Audit Committee characterisitcs and Earnings Quality of listed food and beverages firms in Nigeria. International Scholars Journals, 2(8), 215-227.

Hussaini, T., Bala, R., Gugong, E., \& Benjamin, K. (2015). Board characteristics and earnings management of listed food and beverages Firms in Nigeria. European Journal of Accounting, Auditing and Finance Research, 3(8), $25-41$.

Ibadin, P., \& Dabor, E. (2015). Corporate governance and accounting quality: Empirical investigations from Nigeria. Journal of Policy and Development Studies, 9(2), 157-9385.

Imeokparia, L. (2013). Corporate Governance and Financial Reporting in the Nigerian Banking Sector. Asian Economics and Financial Review, 3(8), 1038-1095.

Johnson, S. G., Schnatterly, K., \& Hill, A. D. (2013). Board composition beyond independence: social capital, human capital, and demographics. Journal of Management, 39(1), 232-262.

Johnston, J. A. (2009). Accruals quality and price synchronicity. PhD Thesis, Louisiana state university,

Juan, M. R. (2012). An empirical examination of ownership structure, earnings management and growth opportunities in Mexican market. International Journal of Business and Social Research, 2(7), 103-123.

Kousenidis, D. V., Ladas, A. C., \& Negakis, C. I. (2013). The effects of the European debt crisis on earnings quality. International Review of Financial Analysis, 30(1), 351-362.

Larcker, D. F., Richardson, S. A., \& Tuna, I. (2007). Corporate governance, accounting outcomes, and organizational performance. Accounting Review, 82(1), 963-1008.

Li, A. S. (2011). The effectiveness of corporate governance in constraining earnings management in Pakistan. The Lahore Journal of Economics, 20(1), 135-155.

Lipe, R. (1990). The relation between stock returns and accounting earnings given alternative information. Journal of Accounting Review, 65, 49-71.

Makhlouf, M., Al-Sufy, F., \& Almubaideen, H. (2018). Board Diversity and Accounting Conservatism: Evidence from Jordan.

Mulbert, P. O. (2010). Corporate governance of banks: European Business Organization. Law Review, 10(2), 411-436

Nelson, M. W., \& George, K. R. (2013). Corporate governance, firm attributes and earnings management in an emerging economy. JAMAR, 11(1), 32-45.

OECD. (2004). Corporate governance report. Retrieved from www.OECD.org

Omar, J. (2017). Audit committee characteristics and earnings management: The case of Bahrain. International Journal of Accounting and Financial Reporting, 7(1), 11-31. 
Ozili, P. (2020). Corporate governance research in Nigeria: a review. Retrieved from https://mpra.ub.uni-muenchen.de/98217/

Peasnell, K. V., Peter, F. P., \& Young, S. (1999). Outside directors, board effectiveness, and abnormal accruals. Working Paper. Retrieved from http://www.ssrn.com

Penman, S. T. (2003). The effects of corporate governance on the informativeness of earnings. Economics of Governance, 8(2), 129-152.

Penman, S., \& Zhang, X. J. (2002). Accounting conservatism, the quality of earnings and stock returns. The Accounting Review, 77(2), 237-264.

Richardson, A., Sloan, R., Soliman, M., \& Tuna, I. (2001). Information in accruals about the quality of earnings. Working Paper, University of Michigan Business school.

Schipper, K., \& Vicent, L. (2003). Earnings Quality. Accounting Horizon, 17, 235-250.

Shiri, M. M., Vaghfi, S. H., Soltani, J., \& Esmaeli, M. (2012). Corporate governance and earning quality: Evidence from Iran. Middle East Journal of Scientific Research, 11(6), 702-708.

Soderstron, R. A., \& Sun, F. H. M. (2007). Board, audit committee, culture and earnings management: Malaysian evidence. Managerial Auditing Journal, 21(7), 783-804.

Soghra, B. N., \& Vakilifard, H. (2015). Meta-analysis of relationship between corporate governance and earnings quality. Indian Journal of Fundamental and Applied Life Sciences, 5(3), 1903-1916.

Spinos, V. (2003). Women directors on corporate boards: A review and research agenda. Corporate Governance: An International Review, 17(3), 320-337.

Srinidhi, B., Gul, F. A., \& Tsui, J. (2011). Female directors and earnings quality. Contemporary Accounting Research, 28(5), 1610-1644.

Wang, L. (2015). Board gender diversity and accounting conservatism: evidence from Finland. Retrieved from www.ssrn.com

Wells, S. (2010). Can high leverage control the opportunistic behavior of managers: Case analysis of textile sector of Pakistan. International Research Journal of Finance and Economics, 47(1), 14-28.

Yeh, Y., \& Chou, H. (2014). Control-ownership structure, audit committee and earnings management: Evidence from East Asia. Journal of Business Administration and Management Sciences Research, 3(8), 163-183.

\section{Copyrights}

Copyright for this article is retained by the author(s), with first publication rights granted to the journal.

This is an open-access article distributed under the terms and conditions of the Creative Commons Attribution license (http://creativecommons.org/licenses/by/4.0/). 